\title{
Industrial Structure and Economic Resilience of Non-Metropolitan Regions: An Empirical Base for the Smart Specialization Policies
}

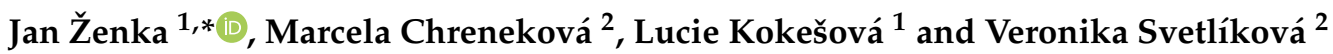 \\ 1 Department of Human Geography and Regional Development, University of Ostrava, \\ 71000 Ostrava, Czech Republic; lucie.kokesova@osu.cz \\ 2 Faculty of European Studies and Regional Development, Slovak University of Agriculture in Nitra, \\ 94976 Nitra, Slovakia; marcela.chrenekova@uniag.sk (M.C.); veronika.svetlikova@uniag.sk (V.S.) \\ * Correspondence: jan.zenka@osu.cz; Tel.: +420-777-930-458
}

Citation: Ženka, J.; Chreneková, M.; Kokešová, L.; Svetlíková, V. Industrial Structure and Economic Resilience of Non-Metropolitan Regions: An Empirical Base for the Smart Specialization Policies. Land 2021, 10, 1335. https://doi.org/10.3390/ land10121335

Academic Editor: Francisco Manuel Parejo-Moruno

Received: 4 November 2021

Accepted: 25 November 2021

Published: 3 December 2021

Publisher's Note: MDPI stays neutral with regard to jurisdictional claims in published maps and institutional affiliations.

Copyright: () 2021 by the authors. Licensee MDPI, Basel, Switzerland. This article is an open access article distributed under the terms and conditions of the Creative Commons Attribution (CC BY) license (https:// creativecommons.org/licenses/by/ $4.0 /)$.

\begin{abstract}
In this paper, we aim to describe and explain the regional disparities in economic resilience in Slovakia in the period 1997-2017. We focus on the effects of economic structure in combination with the vertical (potential accessibility) and horizontal geographical location. Since the early 1990s, Slovak (non-)metropolitan regions exhibited deep changes in the sectoral structure of the economy that were followed by sharp unemployment increases. Due to the FDI-fueled economic growth in the last two decades, however, considerable progress in regional economic growth and reduction in unemployment was recorded. Therefore, Slovak non-metropolitan regions provide valuable lessons for the analysis of regional economic resilience in a long-term period. We ask if, and to what extent were, the prospects of regional renewal after economic crises associated with the geographical location, economic diversity, firm size and sectoral structure of the economy. We employed spatial regression models to test the effects of the potential accessibility, horizontal geographical location and industrial diversity, and sectoral (agriculture, manufacturing) and firm size structure. The dependent variable, Economic Resilience, was measured by the Regional Development Index, combining the indicators of demographic ageing, net migration, income per capita and registered unemployment rate. Potential accessibility and horizontal geographical location were the key predictors of regional economic resilience. Districts with tertiarized and diversified industrial and firm size structures scored, on average, higher in RDI than specialized districts with large firms and/or a high share of agriculture/manufacturing in total employment.
\end{abstract}

Keywords: non-metropolitan regions; rural regions; economic resilience; smart specialization; industrial structure; Slovakia

\section{Introduction}

While many authors investigated the relationships between economic structure and regional economic resilience [1-9], several topics have not yet been sufficiently covered. With a few exceptions [10], the economic resilience of non-metropolitan regions remains surprisingly underexplored. The majority of papers deal either with the entire regional system, including the effects of large metropolitan regions, or focus directly on a specific type of regions, such as rural [11], peripheral [12,13], old industrial regions [14,15], resourcebased cities [16] or inner areas [17]. It is not common to consider and compare the prospects of resilience between various types of non-metropolitan regions, including peripheral, rural, (old) industrial regions or regions dominated by a single large enterprise.

Few studies also deal systematically with the question of how the geographical scale might affect the potential relationships between economic structure and resilience. The effects of the sectoral or firm size structure, industrial specialization/diversity and (un)related variety at the NUTS2/NUTS3 level might be significantly different from the effects observed 
at a local or microregional level. The positive effects of economic diversity, (un)related variety or diversified specialization on regional resilience are more relevant for larger metropolitan and urban regions than for their non-metropolitan, rural or peripheral counterparts, the lack of a minimal critical size allowing for agglomeration economies to take effect [10,18-22]. In addition, most papers focus on the short-term effects of economic (mostly sectoral) structure on (un)employment volatility or economic performance. It is less clear to what extent current sectoral/industrial and firm size structures affect longer-term regional economic renewal.

Most importantly, geographical contexts and their effects on economic resilience also deserve attention. According to Martin et al. (2016) [8], regional contexts might be more important predictors of economic resilience than industrial structure. The position in the urban hierarchy, inherited industrial/firm size structure, local institutions, culture and social capital mediate the effects of economic structure on regional resilience. Little is known about the effects of industrial structures inherited from the socialist era, such as a legacy of large former state-owned enterprises or weak local economic linkages [10,23,24]. The same also applies to potential connections between smart specialization and longerterm prospects of regional economic growth.

In this paper, we aim to fill this gap, describing and explaining disparities in economic resilience among Slovak non-metropolitan regions, focusing on the effects of economic structure in the period 1997-2017. The novelty of our paper and our primary scientific motivation can be summarized in five major points. Firstly, we try to link two distinct concepts: regional economic resilience and smart specialization, describing and explaining the former to derive policy implications on how to adjust smart specialization policies. Secondly, we aim to contribute to the research on relationships between economic structure and resilience directly in non-metropolitan regions, controlling for the effects of metropolitan cores and their commuting hinterlands. In contrast to the papers dealing with mostly rural or peripheral areas that constitute only one type of non-metropolitan region, we include regions that remain largely neglected: (old) industrial non-metropolitan regions, single (manufacturing) company regions and "normal regions" [23], industrialized nonmetropolitan regions with technologically unrelated industries that do not form a local production system $[24,25]$. Thirdly, we supplement previous papers that dealt with the economic resilience and smart specialization of European regions, mostly at the NUTS2 level, by a district-level analysis to determine if the observed effects of economic diversity, unrelated variety and the sectoral structure of the economy on regional resilience also occur at the microregional scale. Fourthly, we also aim to determine if short-term effects of economic structure on regional economic resilience such as the absorption of employment by agriculture or a portfolio effect associated with a diversified economy also occur in the long term.

Finally, we ask if relationships between economic structure and regional resilience, observed mostly in Western or Southern European countries, also affect Central European regions, where industrial/firm size structures inherited from the socialist era affected their trajectories of socio-economic transition in the 1990s and 2000s [10]. Slovakia was selected as it was a country that experienced rapid changes in the sectoral and industrial structure of employment [26-28]. Structural shifts from agriculture and industry to the service sector were followed by a sharp unemployment increase at the regional level. In 2001, when the unemployment in the country reached $19.2 \%$, almost one-third of Slovak districts reported an unemployment rate higher than $25 \%$ [29]. The turn of the millennium and the first decade of the 21st century, on the other hand, brought successful, FDI-fuelled economic growth, selective reindustrialization and a substantial reduction in unemployment, except for several districts close to the border with Hungary [29]. The economic crisis in 2008-2009 altered regional patterns of (un)employment dynamics, and was followed by another wave of employment growth. These turbulences in the pace of economic development and profound structural changes provided Slovak non-metropolitan regions with an interesting case for the analysis of regional economic resilience and adaptability. 
In our view, regional economic resilience is based on the concepts of robustness, modularity and redundancy [30]. Robustness can be viewed as an ability of a regional economy to maintain its core functionalities and performance against perturbances [31], which might be associated with necessary structural changes [32]. Modularity refers to the features of a regional economy characterized by weak linkages between its industries and firms. While weak local/regional embeddedness are unfavourable for the prospects of value creation and capture [33] or smart specialization [34], as well as the ability to nurture new industries/development paths [35], sector-specific shocks in loosely interconnected regional economies should not diffuse into the whole system. Redundancy is an ability of a regional economy to achieve high employment and economic performance through different combinations of industries, due to their related, complementary or overlapping functions [30].

Departing from the concepts of robustness, modularity and redundancy, regional economic resilience is defined in our paper as 'the capacity of a regional or local economy to withstand or recover from the market, competitive and environmental shocks to its developmental growth path, if necessary by undergoing adaptive changes to its economic structures and its social and institutional arrangements ... ' [30] (Martin, Sunley 2015, p. 13). Rather than focusing on a short-term ability to return to the pre-crisis level of economic growth, known as engineering resilience [36], we focus on adaptive resilience, defined as the capacity of a regional economy to adapt its structure to maintain the economic and employment dynamics [36]. In our view, resilient non-metropolitan regions are distinguished primarily by their ability to maintain the higher pace of economic growth in longer-term, post-crisis periods than their counterparts, not primarily by their short-term economic and employment stability or fluctuation.

There are many ways in which the economic structure might affect regional resilience. What is important is the diversity or specialization of economic activities, integration into supply chains, firm size and ownership structure, local economic linkages and several other aspects described by $[8,30]$ Martin and Sunley $(2015,2016)$. For this paper, we stick to measurable and quantifiable aspects of regional economic resilience:

i. sectoral structure: sensitivity of regional economies to a negative sector-specific shock [35], focusing on the role of agriculture, considering also manufacturing, construction and services for a comparison;

ii. economic diversity and the role of unrelated variety [37];

iii. firm size structure.

In the second section, we propose a theoretical framework linking the economic structure and economic resilience of non-metropolitan regions. More specifically, we discuss the effects of the sectoral structure of employment, economic diversity/(un)related variety and firm size structure, together with intervening variables such as horizontal and vertical geographical location. Data sources and methods are described in the third section. Then, we provide a brief contextualization of Slovak regions in the fourth section, focusing on the west-east gradient in socioeconomic performance, characteristics of the subperiods (1997-2001; 2002-2007 and 2008-2017) and economic structures inherited from the socialist era. The fifth section presents the most important empirical results. The sixth section discusses our results in the context of other relevant papers. The final section concludes and proposes several policy implications and suggestions for future research.

\section{Economic Structure and Regional Resilience}

As already suggested above, an economic structure might affect regional resilience through the effects of the sectoral structure, and the specialization/diversity of industrial and firm size structure. The sectoral structure of the economy and its sensitivity to sectorspecific shocks is one of the most intensively studied factors of regional economic resilience. Let us start with the primary sector. Regional specialization in agriculture is expected to be associated with higher resistance and lower unemployment volatility in the (post)crisis period due to the non-cyclical character of this sector. There is substantial empirical 
evidence supporting this thesis [3,4,7]. Other studies, however, found no significant [2] or even adverse effects in the short term [6].

The results are not conclusive for several reasons. The above-mentioned papers vary in the geographical scales of their analyses; while [2] Ezcurra (2011), [6] Crescenzi et al. $(2016)$ or $[3,4]$ Giannakis and Bruggeman $(2017,2020)$ dealt with regional disparities in the EU/member countries at the NUTS2 level, [7] Faggian et al. (2018) focused on intra-state differences at the level of local labour areas. Moreover, large differences in geographical contexts might also affect the relationship between the share of agriculture and regional resilience. Metropolitan and peripheral EU NUTS2 regions might vary in their economic dynamics more than local labour areas or districts in one country. In the $\mathrm{EU}$, the highest specialization in agriculture can be found in Mediterranean peripheries and economically lagging regions in some new EU member states (Poland, Romania, Bulgaria). The former are relatively highly vulnerable to competition from lower-cost countries, showing relatively high unemployment volatility during the 2008-2009 global economic crisis [2]. It is thus unlikely that their agricultural sector would be able to stabilize these regional economies, nor is it likely for the latter. In the last two decades, FDI-fuelled economic growth and a shift from agriculture towards manufacturing and services in many peripheral/rural regions in the new EU countries were associated more with higher unemployment volatility than with stability (see [38] Pavlík and Ženka 2020 for empirical evidence from Romanian regions). Therefore, in highly industrialized Slovak districts characterized by lower-productivity agricultural systems in the European context [39], agriculture might act as an economic stabilizer, perhaps more successfully than in the Mediterranean and Eastern European peripheral/rural areas.

More importantly, it is questioned whether the positive (stabilization) effects of agriculture on regional economic resilience also occur in longer periods, not only during and immediately after major economic slowdowns. Three basic scenarios are possible. In the first, agriculture (either productive or ecological) is highly competitive, sufficient for an acceptable pace of economic and employment growth, in combination with other related industries such as the manufacture of food products [40]. In the second scenario, the persistently high share of low value-added agriculture (especially in regions dominated by technologically unrelated industries) constrain economic growth. Higher unemployment and below-average wage levels lead to a vicious cycle of depopulation, ageing, decreasing local demand, low business creation and unsustainability of local infrastructure and services [41]. In the third scenario, a rapid shift of employment from agriculture to higher value-added and technology/skill-intensive industries [38] is associated with temporary job losses, but more dynamic and resilient regional economies in the long run. The last scenario seems to be the most probable. With the growing interconnectedness of activities through global production networks, the risk of spreading the negative effects of economic recession from metropolitan and urban regions to rural areas also increases.

The role of manufacturing, construction and services in regional resilience is even more ambiguous and harder to predict due to large differences in capital/technology/skill intensity among particular manufacturing and service industries. In general, there is a consensus that, in the short run, manufacturing might increase the volatility of local employment and economic output $[4,42]$, while services should absorb at least temporary disturbances and act as a stabilizer of local economies, especially public services [43]. Construction is considered even more cyclical than manufacturing, exhibiting rather adverse effects on regional resistance [4]. Rural regions have long been characterized by a higher share of public services in employment, which can play a stabilizing role in times of recession (so-called sheltered economies). However, the recovery phase regions, with a high share of public services, usually develop slower than their production-oriented counterparts [5].

Apart from the effects of sectoral structure, regional economic resilience should be positively associated with overall economic diversity $[8,9,44,45]$. Diverse regional economies may benefit from a portfolio effect, reducing the risk of the decline of the regional econ- 
omy [46,47], and higher adaptability due to the variety of firms, industries, institutions and skills that foster the economic/innovation performance and localized spillovers [37,44]. Non-metropolitan regions dominated by a single industry or even by a single firm are generally more vulnerable, less adaptable [36], more susceptible to lock-ins [45], less entrepreneurial and less innovative [44,48]. Small- and medium-sized firms in regions dominated by the large firm(s) may be less able to capture the benefits of agglomeration economies than firms in regions with less concentrated firm size structures [49,50], so-called regional industrial dominance. By contrast, regional economies might be stable when they are dominated by large competitive firms in capital and technology-intensive industries [1]

When considering the potential effects of economic diversity on regional economic resilience, it is vital to distinguish between the related and unrelated variety [37]. In the long term, related variety should lead to higher adaptability, allowing for more efficient local labour market matching, the recombination of knowledge in existing and developing new industries through diversification into new growth paths [9]. Nevertheless, a tightly skill-related and interconnected industrial structure might be seriously harmed by sectorspecific shocks that may diffuse into the entire regional economy [35]. Therefore, regions characteristic of an unrelated variety might absorb an external sector-specific shock more successfully than regions with skill-related industries. This short-term adaptation can be at the expense of their long-term adaptability and pace of economic growth.

While economic diversity and (un)related variety are most likely the most important structural predictors of regional economic resilience; their positive short-term effects on employment stabilization and long-term effects on technological diversification and innovation are relevant rather for large metropolitan regions, as opposed to smaller nonmetropolitan, rural or peripheral regions [48,51]. Therefore, the economic performance of non-metropolitan regions might be more associated with specialization [52], namely smart diversified specialization [53]. Existing evidence suggests that horizontal (sector-neutral) policies in the EU strengthened the innovation potential of the most developed (mostly) metropolitan regions, while less advanced and transition regions were largely unable to capitalize on the development of generic factors [54].

A shift towards smart specialization policies includes designing sector-specific initiatives that reflect accumulated local assets and capabilities, on which new growth paths in skill-related industries and associated local spillovers can be based [34]. Instead of searching for completely new high-tech industries, "smart specialization processes reflect the capacity of an economy to generate new activities aiming at transforming the structures ... It does not aim either at narrowing down the development path of a region or producing some sort of technological monoculture" [34] (Foray 2016, pp. 1430-1431). This does not mean that the path development in non-metropolitan regions must be based purely on endogeneous assets. [55] Balland and Boschma (2021) documented the importance of complementary interregional linkages for the diversification of new growth paths. Even more importantly, the endogenous development of new growth paths and the processes of entrepreneurial discovery [56] in structurally weak regions such as the peripheries or old industrial regions might be constrained by their insufficient institutional capabilities [53]. No matter if endogenously or exogenously stimulated, "structural changes as the main outcome of a smart specialisation process invariably involve some kind of related diversification, a process that builds upon existing capabilities and industrial knowledge and that is animated by the development of R\&D and innovation activities" [56] (Foray and Goenaga 2013, p. 6).

The effects of industrial/firm size structures on rural resilience can be mediated by the position of rural centres in the urban hierarchy, the transport accessibility [22], as well as the various regional contextual factors [10]. The positive effects of economic diversity should be expected more in non-metropolitan regions close to the metropolitan cores than in rural peripheries [57]. Regions in or close to metropolitan hinterlands capitalize on the proximity of large diversified markets, the labour pool and agglomeration economies in metropolitan cores ('effect of borrowed size') while avoiding agglomeration diseconomies [58]. In addi- 
tion, they may become a target for several cost-motivated relocations of firms or institutions from the metropolitan cores or attract urban entrepreneurs, who establish new firms in the rural hinterlands of large cities [59]. Rural peripheries, on the other hand, are much less likely to capitalize on urbanization economies and the portfolio effect [60]. Their small economic bases and labour markets lack a critical mass for agglomeration economies and may face an excessive fragmentation of their production capacities [10].

As suggested above, regional economic resilience is related not only to the short-term fluctuations in employment and gross value added per capita but also to the quality of life [61]. This is a two-way relationship. On the one hand, economic decline as a result of an external shock might harm local product markets, the quality of services and amenities, and economic resilience, thus affecting the prospects of local quality of life. On the other hand, quality of life might foster regional competitiveness and resilience, especially in regions characterized by high social capital endowments [62]. Soft localization factors [63], including amenities [64] might be critical for the attraction of a highly skilled and creative labour force [65], entrepreneurs, firms in knowledge-intensive economic activities [25] and corporate headquarters. Moreover, the ability to prevent a systematic outmigration of a highly skilled labour force [66] is critically important especially in economically lagging peripheral or old industrial regions.

Departing from the theoretical discussion above, we formulated the following research questions about the economic resilience of Slovak (non)metropolitan districts in the period 1997-2006 and 2007-2017:

RQ1: To what extent was the economic resilience of Slovak districts related to their economic structure in terms of the sectoral structure of employment, unrelated variety and the concentration of the firm size structure?

RQ2: To what extent was the economic resilience of Slovak districts affected by other intervening variables, including urban hierarchy, horizontal geographical location and regional contextual factors.

\section{Materials and Methods}

Slovak (non)metropolitan regions were delimited at the level of districts (Local Administrative Units-LAU1). This is the most detailed spatial level in Slovakia, at which several regional policies can be efficiently implemented (see [67] Abreu et al. 2019 for a similar approach), and where it is possible to collect all relevant data. For this paper, nonmetropolitan regions are defined as all districts that are not classified as metropolitan urban areas by the [68] OECD (2012: Redefining Urban (see Figure 1). While districts surrounding the metropolitan cores, Bratislava and Košice, are considered by several authors as functional urban regions-FUAs [69], we included them into the group of non-metropolitan regions to contrast them with peripheral non-metropolitan regions. In addition, using FUAs hides sharp inner disparities between economically more developed urban cores and the lagging rural hinterland of the FUA [70].

Considering the methodology (Figure 2), we started by collecting the firm-level data for districts with aggregation at the 2-digit level. NACE industries (rev. 1.1). Next, indicators covering the industrial and firm size structure (see Table 1) were calculated. In Geoda, we also constructed a spatial weight matrix for measuring the potential accessibility and horizontal geographical location. We also calculated the Moran I, necessary for checking the rate of spatial autocorrelation. After the collection of all data (available as the Supplementary Materials) and construction of all explanatory variables and the dependent variable (see below), we ran univariate (mostly spatial lag) regression models that tested the effects of all predictors. Next, we also conducted multivariate regression models. Both univariate and multivariate models were conducted for all Slovak districts and separately for the group of non-metropolitan regions. 


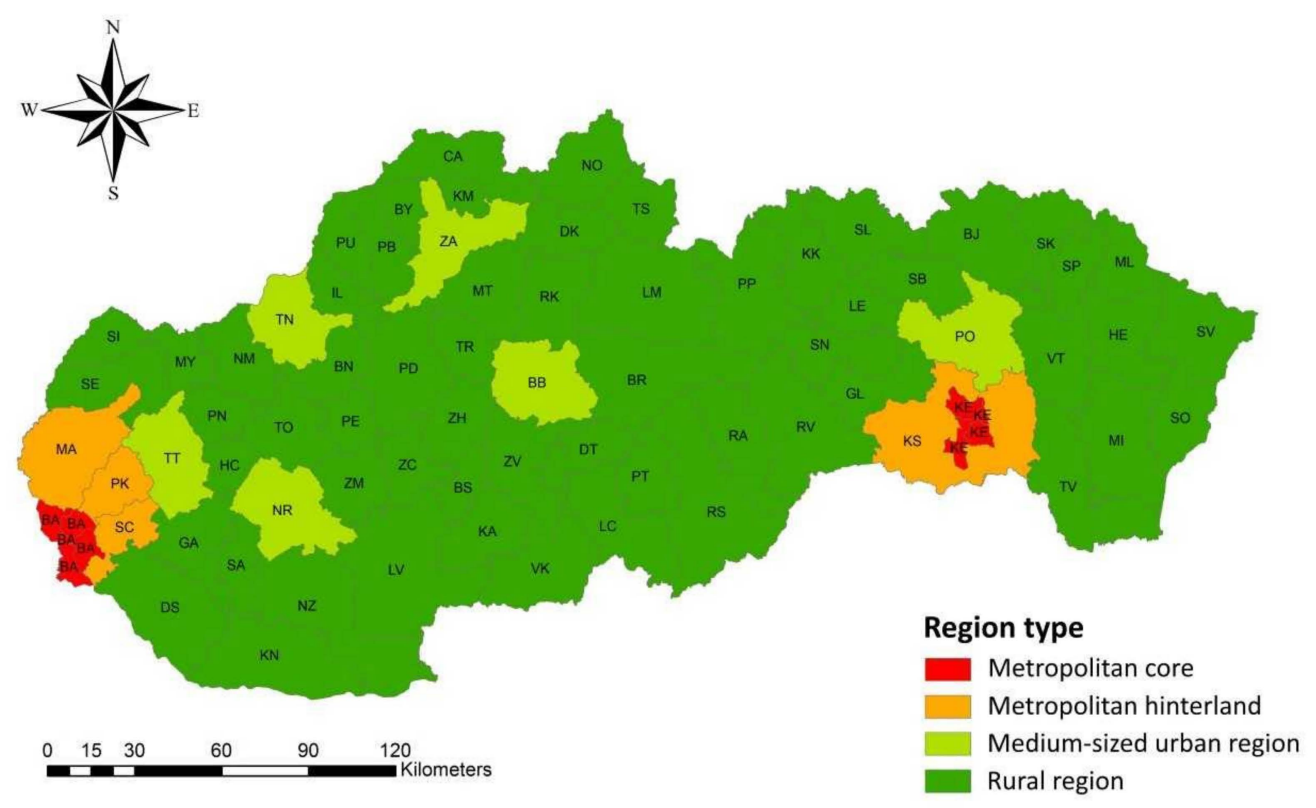

Figure 1. Typology of Slovak regions. Source: OECD 2012; the authors.

Table 1. Variables used for the construction of the RDISK (years 1997, 2007, 2017).

\begin{tabular}{ccccc}
\hline Variable & Indicator & Unit & Abbreviation & Data Sources \\
\hline Migration & $\begin{array}{c}\text { Net migration as a share of the total population } \\
\text { Demographic Dependency Index; population (65+) } \\
\text { plus population (0-15) divided by the population in } \\
\text { the working-age (15-64) }\end{array}$ & $\%$ & MIGR & [71] \\
Income & Mean annual income per household & AGIN & [72] \\
Unemployment & Registered unemployment rate & INCO & {$[73]$} \\
\hline
\end{tabular}

Sources: [67] Abreu et al. (2019) and the authors.

The dependent variable is the Regional Development Index (RDISK), inspired by the complex multidimensional Rural Development Index (RDI) proposed by [67] Abreu et al. (2019, p. 1111-1112). The RDI has four pillars, each containing four indicators that measure the following:

Demographic (population density, natural increase, net migration, ageing);

Social (literacy, education, healthcare, housing);

Economic (agricultural employment, income, purchasing poverty, employment);

Environmental dimensions (municipal environmental expenditures, waste and wastewater treatment, share of Natura 2000).

We simplified this index, modified it to also measure the quality of life in urban regions and excluded indicators that were not available at the district level in Slovakia. The unavailable employment rate at the district level was replaced by the registered unemployment rate. We focused on the periods 1997-2006 and 2007-2017. The year 2006 may be considered as the end of the first period of Slovak transition from socialism to capitalism [27], while the period 2007-2017 covers changes since joining the EU, impacts of the 2008-2009 global economic crisis and post-crisis economic recovery.

Our proposed $\mathrm{RDI}_{\mathrm{SK}}$ index is composed of four demographic/socioeconomic indicators that should be sensitive enough to reflect long-term impacts of economic shocks: net migration, ageing, income per capita and unemployment rate (Table 1). Net migration is the difference between immigration into a region and emigration from a region during a given year, which reflects residential and/or work appeal. The indicator, Ageing, showed not only population dynamics but also the availability of labour, as well as current and future social support requirements of the regional population [67]. Income was a key 
indicator of regional economic performance and living standards, likely the most sensitive indicator to fluctuations during the economic cycle. The unemployment rate reflected socioeconomic sustainability and the social impacts of an economic crisis.
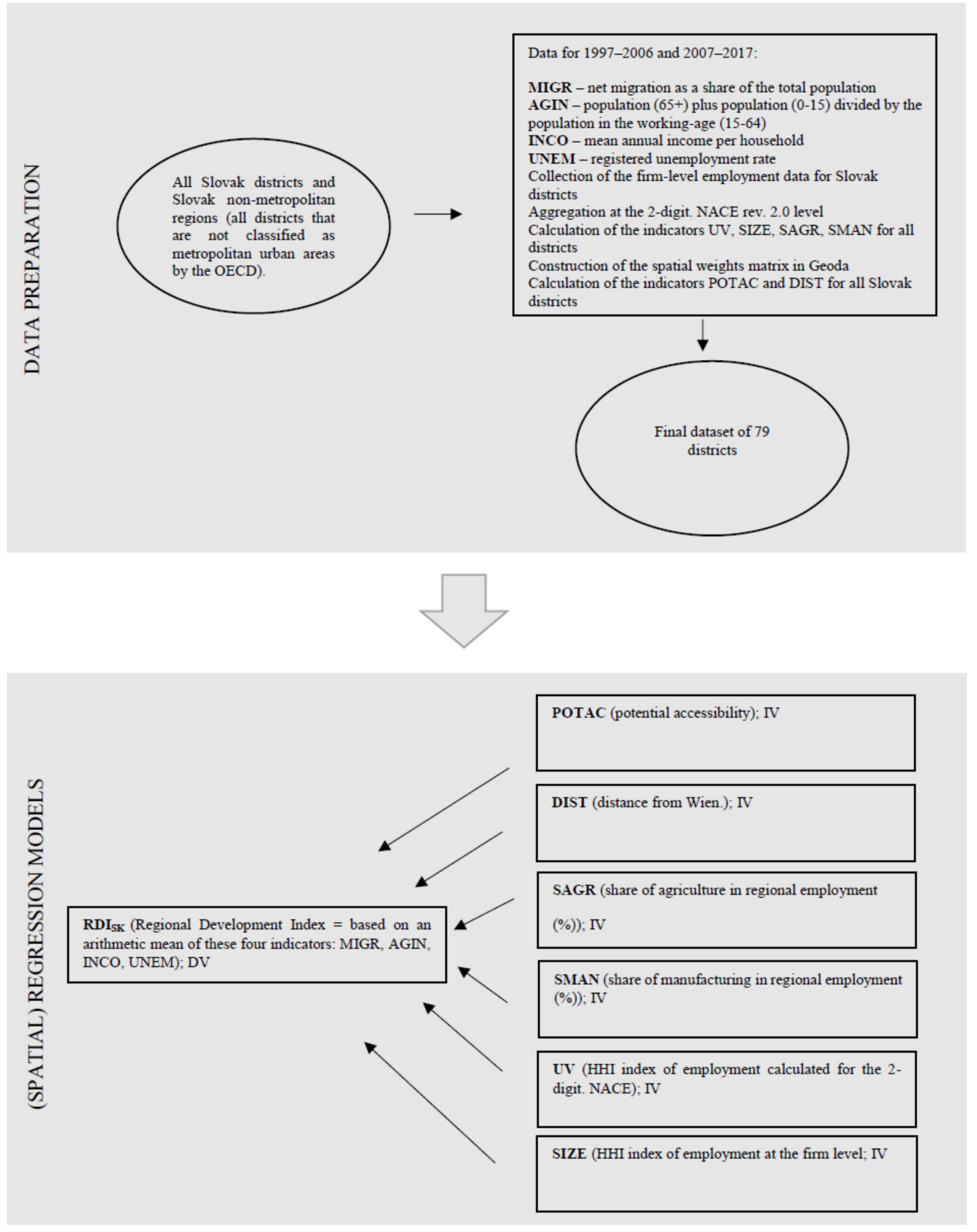

Figure 2. Flow chart: methodology of the paper. Source: the authors.

The Index is based on an arithmetic mean of these four indicators:

$$
R D I_{S K}=\frac{M I G R+A G I N+I N C O-U N E M}{4}
$$


The values $R i$ of the indicator $R$ (components of the-MIGR, AGIN, INCO and UNEM) entering into the calculation of the index were normalized, using the Min-Max scaling:

$$
R_{\text {norm }}=\frac{R_{i}-\min (R)}{\max (R)-\min (R)}
$$

To explain the regional variation in the $R D I_{S K}$, we employed several regression models. Our dataset was not rich enough to use models with fixed or random effects, so we ran pooled regression models. Because our dataset was relatively small (79 districts), we aimed to minimize the number of explanatory variables (Table 2). In Slovakia, economic data available for the LAU1 units were aggregated at the 2-digit level. While we were unable to measure related variety, the data allowed us to compute the rate of economic diversity and, at the same time, unrelated variety $(U V)$. Therefore, economic diversity/specialization and $U V$ [37] were measured by the Herfindahl-Hirschmann index and calculated as:

$$
U V=\sum_{i=1}^{n} E S_{n}^{2}
$$

where ES is the share of the 2-digit NACE industry in regional employment and $n$ is the number of all industries. Low values indicate the dispersed economic structure and unrelated variety, while high values reflect industrial specialization.

The positions of rural centres in the urban hierarchy were expressed as to potential accessibility [75], or a sum of pairwise distances between all rural centres [76] (see Randák et al. 2021 for more detailed elaboration):

$$
\text { POTAC }=\sum_{i=1}^{n} P_{i}+\sum_{j=1}^{n} P_{j} / d_{i j}
$$

where $d_{i j}=$ distance between place $\mathrm{i}$ and $\mathrm{j}$ (derived from valued graph matrix), $\mathrm{P}_{\mathrm{j}}$ is an 'economic aggregate' of a place $j$ (population multiplied by mean annual income per capita),

\begin{tabular}{|c|c|c|c|c|c|}
\hline Variable & Type & Indicator & Abbrev. & Period & Data Source \\
\hline Economic Resilience & DV & Regional Development Index & $\mathrm{RDI}_{\mathrm{SK}}$ & $\begin{array}{l}\text { 1997; 2007; 2017; } \\
\text { 1997-2007; } \\
\text { 2007-2017 }\end{array}$ & [71-74] \\
\hline $\begin{array}{c}\text { Vertical Geographical } \\
\text { Location } \\
\text { Horizontal }\end{array}$ & IV & $\begin{array}{l}\text { Potential accessibility (weighted) } \\
\text { of the district centroids }\end{array}$ & POTAC & $1997 ; 2007 ; 2017$ & {$[73,77]$} \\
\hline $\begin{array}{l}\text { Geographical } \\
\text { Location }\end{array}$ & IV & Distance from Wien & DIST & $1997 ; 2007 ; 2017$ & {$[73,77]$} \\
\hline Agriculture & IV & $\begin{array}{c}\text { Share of agriculture in regional } \\
\text { employment }(\%)\end{array}$ & SAGR & 1997; 2006; 2016 & [78] \\
\hline Manufacturing & IV & $\begin{array}{l}\text { Share of manufacturing in } \\
\text { regional employment }(\%)\end{array}$ & SMAN & $1997 ; 2006 ; 2016$ & [78] \\
\hline $\begin{array}{c}\text { Economic } \\
\text { Diversity/Unrelated } \\
\text { Variety }\end{array}$ & IV & $\begin{array}{l}\text { HHI index of employment } \\
\text { calculated for the 2-digit. NACE }\end{array}$ & UV & 1997; 2006; 2016 & [78] \\
\hline Firm Size Structure & IV & $\begin{array}{l}\text { HHI index of employment at the } \\
\text { firm level }\end{array}$ & SIZE & 1997; 2006; 2016 & [78] \\
\hline
\end{tabular}
and $n=$ number of locations.

Table 2. Variables employed in regression models.

Note: $\mathrm{DV}=$ dependent variable, IV = independent/explanatory variable. Source: the authors.

In addition, we also employed a horizontal geographical location to capture the potential west-east gradient in economic performance due to the proximity to the borders with the more developed nation of Austria. Euclidean distances between all Slovak district towns and Wien, the Austrian capital, were calculated. 
The sectoral structure was expressed as a share of agriculture, manufacturing and services in total regional employment. Finally, the firm size structure was measured by the Herfindahl-Hirschmann index of employment, calculated at the firm level:

$$
S I Z E=\sum_{i=1}^{n} S_{n}^{2}
$$

A Lagrange Multiplier Test revealed significant spatial autocorrelation of the dependent variable, so it was necessary to employ spatial regression models (see the Results section).

\section{Contextualization}

Slovakia (the Slovak Republic) was established on 1 January 1993. In the period 1993 1996, Slovak regions experienced dramatic shifts in the sectoral structure of employment as a result of three processes: globalization, marketization and post-industrialization [26,79]. Rapid decreases in agricultural and industrial employment occurred in almost all nonmetropolitan regions, leading to a gradual growth of the service sector [27]. Deep structural changes were followed by a spatial polarization of the socio-economic development and high unemployment rates in many regions [70] (see Figure 3). Sharp unemployment increases were recorded in rural agricultural peripheries, mostly in central and eastern parts of the country and in regions that were over-industrialized during the era of socialism, often hosting large branch plants of the former socialist industrial enterprises [80]. In the 1990s, only a minority of rural regions were able to develop new paths of industrial development [81]. Their adaptability was rather low, resulting from a former socialist overspecialization, and leading to various forms of regional lock-in, low levels of productivity, entrepreneurial activity and related variety.

Moreover, there was a pronounced west-east gradient in all socio-demographic and economic indicators. While eastern districts showed generally higher population dynamics [82], they were also characteristic of a significantly higher unemployment rate. Nevertheless, the most economically deprived regions were found among the outer peripheries located along with the Slovak-Hungarian border, with the unemployment rate exceeding $20 \%$. The most economically successful regions, on the other hand, were the metropolitan region of Bratislava, several medium-sized urban regions and highly industrialized non-metropolitan regions, which were dominated by large industrial companies in the western region of the country.

When considering a general trajectory of the economic development in Slovakia, our analyzed period 1997-2017 can be divided into three sub-periods: 1997-2001; 20022007 and 2008-2017. The first five years were characterized by a continuing process of post-socialist transformation and structural shifts from production sectors towards service sectors, followed by high unemployment growth, peaking in 2001. The second period 2002-2007 was characterized by rapid economic growth leading to a substantial reduction in unemployment. A massive inflow of foreign direct investment (FDI) caused a temporary reindustrialization in some rural regions [28]. The third period was affected by the global economic crisis of 2008-2010, with a relatively successful renewal after the crisis. Since the end of the 1990s, FDI inflow has become a major factor of regional economic divergence [80].

The description and explanation of economic resilience and quality of life in Slovak rural regions require a focus on their specific features and contextual factors. In 1997, almost all Slovak rural regions were still highly industrialized, despite their rapid deindustrialization in the first half of the 1990s (Figure 4). The secondary sector accounted for a higher share of employment than the primary sector in all rural districts except for Dunajská Streda [27]. This was a result of excessive socialist industrialization, which aimed to nivelize the socioeconomic disparities between urban and rural areas. Another socialist legacy was a high rate of industrial specialization and concentrated firm size structures in many rural districts [26]. Many of these structures specialized either in heavy manufacturing or armaments industry [83], sectors, and experienced sharp employment decreases in the 1990s. 


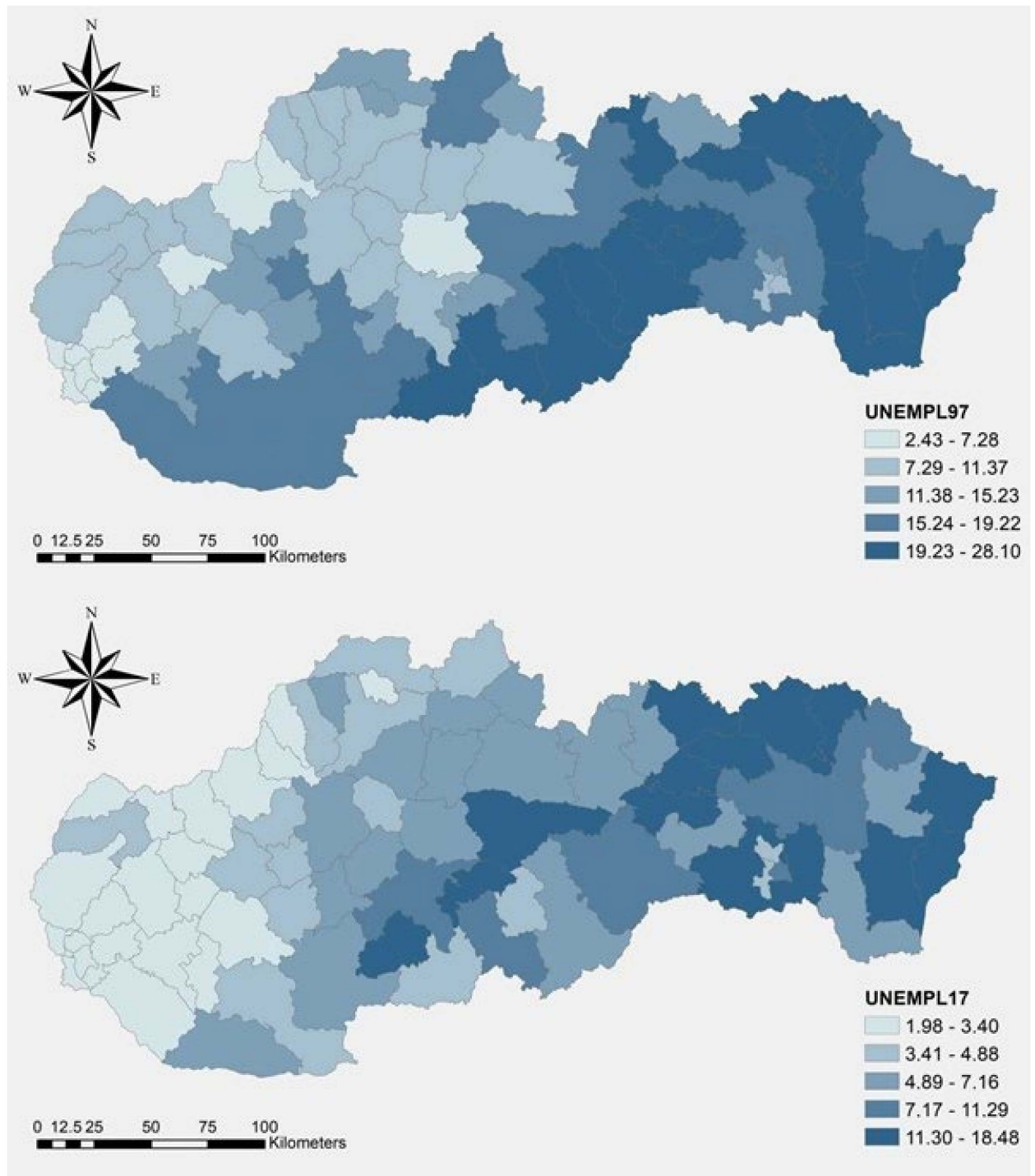

Figure 3. The unemployment rate in Slovak districts 1997 and 2017 (\%). Source: SOSR 2020d.

A traditional west-east gradient [84] in the rate of industrialization and economic growth (more developed and industrialized western parts compared to predominantly agricultural and economically deprived eastern peripheries) persisted in the whole period of our investigation. However, the implantation of large state-owned plants, mostly in technologically unrelated heavy manufacturing or armament industries, transformed most agricultural peripheries into branch plant regions [26]. In addition, the socialist policies, which aimed to achieve regional socioeconomic nivelization, restricted population/economic growth and suburbanization in metropolitan regions. Rural and medium-sized urban regions in Central European socialist countries were strongly supported, which lead to their over industrialization [85]. Similar to the situation in the former East Germany [86], or Czechia [10], many Slovak rural regions were (and, to a certain extent, remained) characterized by weaker local inter-firm linkages, due to the legacy of socialist, state-owned, vertically oriented enterprises that were often headquartered in large cities and their production facilities in rural areas. 


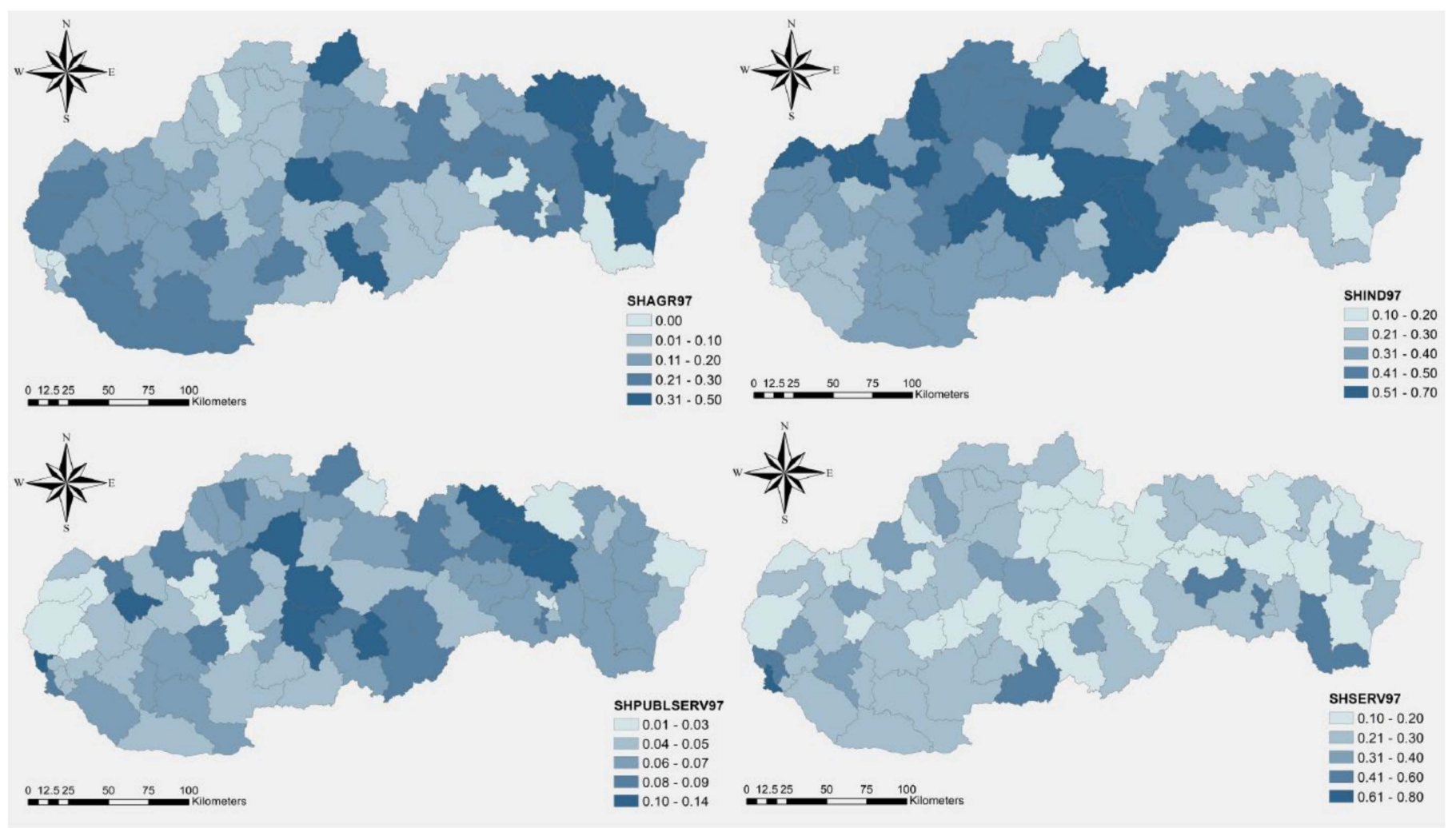

Figure 4. Share of agriculture, industry, services and public services in total employment—1997 (\%). Source: [78] Rusnák and Lehocký 2016.

\section{Results}

Sharp regional disparities and the west-east gradient of unemployment in the late 1990s were documented in the previous section. Correspondingly, sharp regional disparities were also documented for the RDI 1997 (Figure 5); the west-east gradient was even more pronounced, with the outer peripheries in the eastern part of the Košický and Prešovský NUTS3 region scoring the lowest. At the same time, a position in the urban hierarchy of Slovakia was similarly important; a positive association $(R=0.54)$ between the potential accessibility and overall $\mathrm{RDI}_{\mathrm{SK}}$ score is visible. While the metropolitan core of Bratislava was surrounded by well-performing districts (both from an economic and socio-demographic point of view; see [87] Hübelová et al. 2021 for similar conclusions from Czechia) in its metropolitan hinterlands, the effects of the Košice metropolitan region and regional capitals were not strong enough to affect the surrounding regions.

Despite turbulent economic changes in the period 1997-2007, the overall regional pattern of $\mathrm{RDI}_{\mathrm{SK}}$ did not change substantially (Figure 5). Nevertheless, this period was also characteristic of regional convergence in the pace of development. A medium-strong negative correlation $(R=-0.38)$ was found between the RDI $S K$ in 1997 and the 1997-2007 change in RDISK. Therefore, most of the districts that experienced a substantial improvement in ranking scored rather low in 1997. However, no clear geographical pattern of regional changes in the RDI ranking during the period 1997-2007 occurred. The period 2007-2017 was different. The most economically successful areas were mostly found among the metropolitan and medium-sized urban regions, although several inner and outer peripheries also improved their position considerably.

The regional pattern of $\mathrm{RDI}_{\mathrm{SK}}$ in 2017 was not substantially different from previous years: a combination of the vertical geographical location and the west-east gradient is still highly relevant for explanation of the differences in $\mathrm{RDI}_{\mathrm{SK}}$. Relative regional disparities (standard deviation divided by the mean) virtually did not change in the period 2007-2017. A group of districts that improved their position substantially was highly heterogeneous, 
including several outer peripheries that were hit by high unemployment in the second half of the 1990s, but also several districts in metropolitan hinterlands, regional capitals and highly industrialized regions located primarily in the western part of Slovakia.
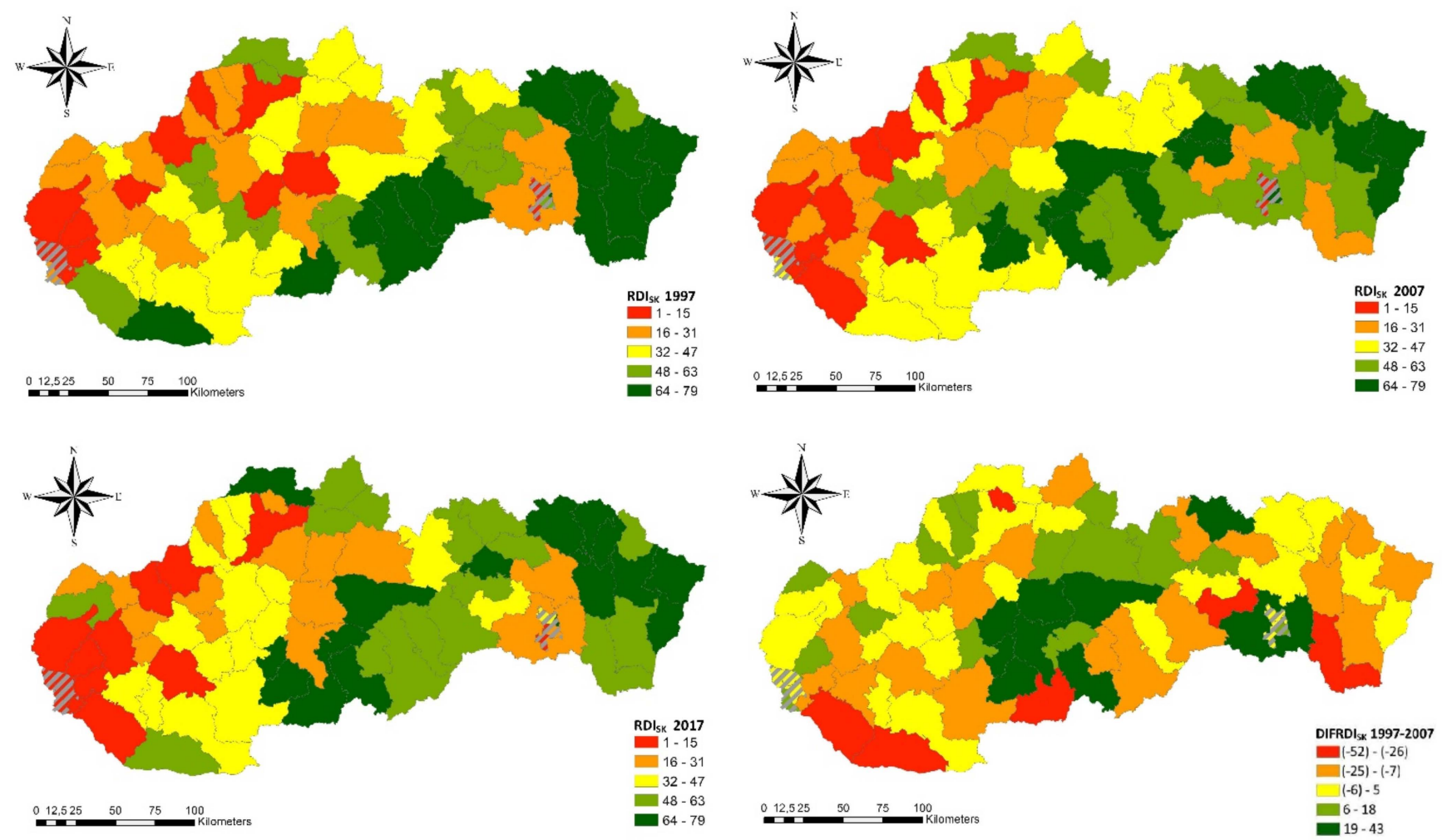

Figure 5. RDI $\mathrm{SK}_{\mathrm{K}}$ for Slovak districts in 1997, 2007 and 2017. Source: the authors.

In the second part of our empirical section, we employed several regression models explaining regional variations of the RDI $_{S K}$ between 1997 and 2017 (Table 3). To test the effects of economic structure, we used classic OLS, spatial lag and spatial error models. Firstly, univariate regression models that tested the effect of a single predictor were used. Secondly, multivariate models that combined industrial specialization, firm size structure and specialization in agriculture/manufacturing with vertical/horizontal geographic location were employed. After several pretests, we excluded the interaction effects between vertical/horizontal geographical location and industrial specialization, because no interactions showed significant effects. Out of all the combinations, we selected only the most parsimonious models with the highest $\mathrm{R}^{2}$ (Table 3 ). The dependent variable was defined as a rank of a district in the $\mathrm{RDI}_{\mathrm{SK}}$ of all Slovak districts: higher values indicate a worse ranking of a district.

Starting with the year 1997, model 1 explained $35.0 \%$ of the variability in $\mathrm{RDI}_{\mathrm{SK}}$ scores by the Horizontal Geographical Location DIST. The $\mathrm{R}^{2}$ of an alternative model, using the potential accessibility as a predictor, reached $33.0 \%$, both models showed highly

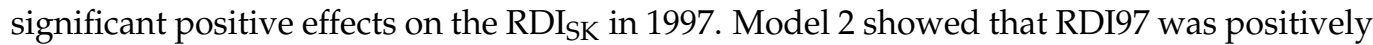
associated with Unrelated Variety and diversified Firm Size Structure, but their effects were not statistically significant. Surprisingly, no models revealed any significant association between Agriculture/Manufacturing and RDI97. The situation in 2007 was different. Model 3 explained $43 \%$ of the variability of the RDI07 by a combination of spatially lagged RDI07 Location and the Vertical Geographical (potential accessibility).

The sectoral structure appeared to be significantly associated with RDI07: both Agriculture and Manufacturing displayed negative effects on $\mathrm{RDI}_{\mathrm{SK}}$, meaning that regions specialized in agriculture/manufacturing scored worse in RDI7 ranking (model 4). The expected effects of the Vertical Geographical Location, Firm Size Structure and Unrelated 
Variety were non-significant; the model has since been excluded. Regional differences in RDI2017 were captured again by the Horizontal Geographical Location, favouring the districts close to the Austrian capital, Wien, and Slovak capital, Bratislava (model 5). While RDI17 was (similarly to RDI97) positively associated with Unrelated Variety and diversified Firm Size Structure, these effects were not statistically significant (model 6). The change in $\mathrm{RDI}_{\mathrm{SK}}$ ranking for the regional patterns of 2007-2017 was so complex that we were unable to explain these patterns by the effects of geographical location and economic structure.

Table 3. Regression models with the $\mathrm{RDI}_{\mathrm{SK}}$ as the dependent variable.

\begin{tabular}{|c|c|c|c|c|c|c|c|}
\hline Dependent Variable & RDI97 & RDI97 & RDI07 & RDI07 & RDI17 & RDI17 & DIFRDI9707 \\
\hline Model number & 1 & 2 & 3 & 4 & 5 & 6 & 7 \\
\hline \multirow[t]{2}{*}{ Constant } & 0.01 & -0.02 & -0.00 & -0.01 & -0.02 & -0.03 & 0.00 \\
\hline & $(0.09)$ & $(0.09)$ & $(0.08)$ & $(0.08)$ & $(0.09)$ & $(0.08)$ & $(0.11)$ \\
\hline \multirow{2}{*}{ WRDI } & $0.45 *$ & $0.72 * * *$ & $0.67^{* * *}$ & $0.70^{* * *}$ & $0.41 *$ & $0.67^{* * *}$ & \\
\hline & -0.18 & -0.12 & -0.12 & -0.12 & -0.19 & -0.13 & -0.21 \\
\hline \multirow[t]{2}{*}{ POTAC } & & -0.04 & $-0.27^{* *}$ & & & -0.08 & $(0.11)$ \\
\hline & & $(0.09)$ & $(0.09)$ & & & $(0.11)$ & \\
\hline DIST & $\begin{array}{l}0.33 \text { * } \\
(0.13)\end{array}$ & & & & $\begin{array}{c}0.40^{* *} \\
(0.13)\end{array}$ & & \\
\hline \multirow{2}{*}{ UV } & & 0.07 & & & & 0.12 & \\
\hline & & $(0.10)$ & & & & $(0.11)$ & \\
\hline \multirow{2}{*}{ SIZE } & & 0.05 & & & & 0.16 & \\
\hline & & $(0.10)$ & & & & $(0.09)$ & \\
\hline \multirow[t]{2}{*}{ SAGR } & & & & 0.14 & & & \\
\hline & & & & $(0.08)$ & & & \\
\hline \multirow[t]{2}{*}{ SMAN } & & & & $0.27 * *$ & & & \\
\hline & & & & $(0.08)$ & & & \\
\hline $\mathrm{N}$ & 79 & 79 & 79 & 79 & 79 & 79 & 79 \\
\hline $\mathrm{R}^{2}$ & 0.35 & 0.33 & 0.43 & 0.46 & 0.42 & 0.43 & 0.04 \\
\hline Rho & 0.45 & 0.72 & 0.67 & 0.70 & 0.41 & 0.67 & \\
\hline \multirow{2}{*}{$\begin{array}{c}\text { Breusch-Pagan Test } \\
\text { Likelihood Ratio } \\
\text { Test }\end{array}$} & 0.31 & 0.56 & 0.20 & 0.53 & 0.03 & 3.40 & 0.64 \\
\hline & $4.48^{*}$ & $21.45^{* * *}$ & $24.37^{* * *}$ & $27.09^{* * *}$ & 4.92 * & $24.39^{* * *}$ & 2.29 \\
\hline
\end{tabular}

Notes: Standard errors are in parentheses. All regression coefficients are mean-centered and scaled by 1 standard deviation. ${ }^{* * *} p<0.001$; ${ }^{* *} p<0.01 ;{ }^{*} p<0.05$. Source: the authors.

The second group of regression models tested the effects of geographical location and economic structure on the RDI $\mathrm{SK}_{\mathrm{K}}$ of non-metropolitan regions (Table 4). Model 7 explained $28 \%$ of regional variability in RDISK97 by the Horizontal Geographic Location. After the exclusion of metropolitan cores, the negative effects of the Firm Size Structure appeared to be significant in 2007 (model 8), together with positive effects of the Vertical Geographical Location and Unrelated Variety. Therefore, in 2007, the districts with higher potential accessibility, diversified industrial and firm size structures scored higher in the RDI07 ranking. Apart from a positive association between the RDI07 and Vertical Geographical Location (potential accessibility), model 9 shows the negative effects of Agriculture and Manufacturing, with only the latter being statistically significant. In 2017, regional differences in RDI17 were once again explained by the Horizontal Geographical Location (model 10). Moreover, positive effects of the potential accessibility and diversified firm size structure (model 11) and negative effects of specialization in agriculture were proven (model 12). If we turn to the changes in the RDI ${ }_{S K}$ in the periods 1997-2007 and 2007-2017, a single predictor showed statistically significant effects: potential accessibility (model 13 and 14). 
Table 4. Regression models with the $\mathrm{RDI}_{\mathrm{SK}}$ as the dependent variable.

\begin{tabular}{|c|c|c|c|c|c|c|c|c|}
\hline $\begin{array}{c}\text { Dependent } \\
\text { Variable }\end{array}$ & RDI97 & RDI07 & RDI07 & RDI17 & RDI17 & RDI17 & DIFRDI9707 & DIFRDI0717 \\
\hline Model number & 7 & 8 & 9 & 10 & 11 & 12 & 13 & 14 \\
\hline Constant & 0.07 & 0.02 & -0.07 & 0.06 & 0.02 & -0.02 & -0.02 & 0.02 \\
\hline & $(0.08)$ & (0.07) & $(0.08)$ & $(0.12)$ & $(0.09)$ & (0.09) & (0.10) & (0.10) \\
\hline WRDI & & $\begin{array}{c}0.71^{* * *} \\
(0.10)\end{array}$ & $\begin{array}{c}0.75^{* * *} \\
(0.10)\end{array}$ & & $\begin{array}{l}0.66^{* * *} \\
(0.14)\end{array}$ & $\begin{array}{c}0.64^{* * *} \\
(0.14)\end{array}$ & & \\
\hline POTAC & & $\begin{array}{c}-0.36^{* * *} \\
(0.09)\end{array}$ & $\begin{array}{c}-0.30 * * * \\
(0.09)\end{array}$ & & & & $\begin{array}{c}-0.44^{* * *} \\
(0.12)\end{array}$ & $\begin{array}{l}0.33^{* *} \\
(0.12)\end{array}$ \\
\hline DIST & $\begin{array}{l}0.52^{* * *} \\
(0.13)\end{array}$ & & & $\begin{array}{l}0.63^{* * *} \\
(0.12)\end{array}$ & & & & \\
\hline UV & & $\begin{array}{c}0.11 \\
(0.07)\end{array}$ & & & & & & \\
\hline SIZE & & $\begin{array}{c}0.26^{*} \\
(0.11)\end{array}$ & & & $\begin{array}{l}0.22 * \\
(0.09)\end{array}$ & & & \\
\hline SAGR & & & $\begin{array}{c}0.13 \\
(0.08)\end{array}$ & & & $\begin{array}{c}0.19 * \\
(0.1)\end{array}$ & & \\
\hline SMAN & & & $\begin{array}{l}0.17^{*} \\
(0.09)\end{array}$ & & & & & \\
\hline $\mathrm{N}$ & 69 & 69 & 69 & 69 & 69 & 69 & 69 & 69 \\
\hline $\mathrm{R}^{2}$ & 0.28 & 0.58 & 0.57 & 0.38 & 0.34 & 0.32 & 0.19 & 0.08 \\
\hline Rho (Lambda) & 0.45 & 0.71 & 0.75 & $(0.38)$ & 0.66 & 0.64 & 0.83 & \\
\hline $\begin{array}{c}\text { Breusch-Pagan } \\
\text { test }\end{array}$ & 0.50 & 3.23 & 0.59 & 1.96 & 1.18 & 0.30 & & 0.82 \\
\hline $\begin{array}{c}\text { Likelihood Ratio } \\
\text { Test }\end{array}$ & & $31.26^{* * *}$ & $33.0^{* * *}$ & 2.93 & $17.58^{* * *}$ & $16.18^{* * *}$ & & \\
\hline
\end{tabular}

Notes: Standard errors are in parentheses. All regression coefficients are mean-centered and scaled by 1 standard deviation. ${ }^{* * *} p<0.001$; ${ }^{* *} p<0.01 ; * p<0.05$. Source: the authors.

To summarize the most important empirical results, we picked three points that deserve attention. Firstly, the regional pattern of RDISK did not change substantially over the 1997-2017 period. Secondly, vertical and horizontal geographical locations showed consistently stronger effects on the dependent variable than economic structure. Thirdly, no significant association between $\mathrm{RDI}_{\mathrm{SK}}$ and industrial/firm size structure inherited from the socialist era was found in 1997, while, in 2007, negative effects of the specialization in agriculture and manufacturing were detected.

\section{Discussion}

There are two basic arguments used by economic geographers to clarify the "mysteries" of uneven regional development. The first explains the concentration of economic growth to particular locations by spatial inequalities in the availability and quality of production factors that foster regional specialization. The second (and more relevant for Slovak districts) brings the structure, performance and strategies of economic actors to the forefront [87]. Departing from the latter approach, most of our empirical models showed relatively weak or insignificant effects of industrial diversity, firm size structure and specialization in manufacturing. This finding contrasts with general discourse in regional economic resilience [8,36] and the conclusions of [25] Ženka et al. (2017), who tested the effects of geographical location and industrial/firm size structure on the economic performance and resilience of Czech non-metropolitan regions, which are in many aspects very similar to Slovak regions. They found strong and positive effects of the dependence on manufacturing, industrial specialization (interaction with population size) and concentrated firm size structure on economic performance, but at the same time, adverse effects on regional employment stability.

Slovak non-metropolitan regions inherited from the socialist era a less favourable industrial structure, often being dominated by large enterprises in capital-intensive (Púchov, 
Žiar nad Hronom, Ružomberok) or labour-intensive industries (e.g., Partizánske). For many Slovak non-metropolitan regions, the industrial base was a key precondition for their development, stimulating not only economic functions but also infrastructure, education or administrative facilities [88]. Large inflows of manufacturing FDIs, occurring since the end of the 1990s, were primarily concentrated into metropolitan regions and regional capitals rather than into non-metropolitan or even peripheral regions. Finally, [10] Ženka et al. (2015) employed value added per capita as the dependent variable, which was more tightly associated with specialized industrial and concentrated firm size structure than a synthetic indicator, also reflecting demographic and social development. While districts with large manufacturing firms are often characterized by relatively high income, they may suffer from high unemployment and outmigration.

Our empirical results concerning the first period of 1997-2006 correspond with the conclusions of [27] Korec (2009): a strong association with the Vertical and Horizontal Geographic Location (for a discussion of different geographical contexts see [89,90]), but ambiguous effects of the sectoral structure. While the share of agriculture and manufacturing in regional employment was negatively correlated with the RDI $\mathrm{IK}_{\mathrm{SK}}$ scores (and positively correlated with the specialization in services), tertiarized economy was characteristic not only for metropolitan and medium-sized urban regions but also for the least developed peripheral regions in (south)eastern Slovakia suffering from high unemployment rates. Correspondingly, highly industrialized non-metropolitan regions included both well-performing districts in the western part of the country and structurally affected laggards [70], often dominated by large manufacturing companies. Smaller districts dominated by a single large manufacturing company were highly diverse in their prospects of $\mathrm{RDI}_{\text {SK }}$ growth; those specialized in lower-tech industries did not experience any significant

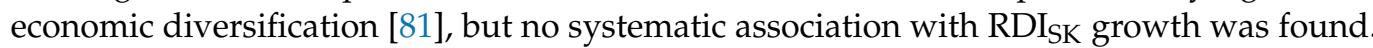

As [78] Rusnák and Lehocký (2016) documented, the industrial diversification of these districts was associated with the declining productivity of local leading industries/firms, followed by unemployment growth and later by the inflow of FDIs into technologically unrelated industries. While Slovak districts dominated by medium or high levels of technology manufacturing experienced economic diversification, districts originally specializing in low/medium-low technology manufacturing mostly preserved their original specialization. The lack of systematic effects in industrial specialization/diversity and firm size structure corresponded with the conclusions of [52] Kemeny and Storper (2015). They argue that the prospects of regional economic growth are more important if a region has (un)favourable specialization than if its economic structure is specialized or diversified. Thus, the $\mathrm{RDI}_{\mathrm{SK}}$ development in Slovak districts was more important if a region inherited competitive firms and if the process of their privatization and restructuring was successful, rather than general structural features of its economy in terms of (un)related variety or specialization, concentrated or dispersed firm size structure.

Our regression models suggest that the effects of vertical and horizontal geographic location remained to be vital predictors of RDISK in the whole period 1997-2017, confirming the findings and assumptions of [27]. Surprisingly, the effects of the economic structure have not changed substantially since 1997, although Slovak districts experienced a shift towards services, a diversification of the firm size structure caused by a decline and/or restructuring of large former socialist state-owned enterprises [81] or an increase in specialization mostly due to the inflow of FDI [78]. This is another confirmation of an assumption that specialization 'on what' is more important than the overall level of economic diversity/specialization [52].

Correspondingly, the share of agriculture and industry in total employment was a more important predictor of $\mathrm{RDI}_{\mathrm{SK}}$ than economic diversity and firm size structure (similar to Czech non-metropolitan regions, as suggested by [10]. More importantly, we did not identify any systematic stabilization effects of agriculture on long-term regional economic resilience. While there was no relationship between the share of agriculture and the intensity of changes in industrial structure since 1997, districts that were originally 
dependent on agriculture in the second half of the 1990s showed above-average increases in $\mathrm{RDI}_{\mathrm{SK}}$ scores over the following two decades. Despite rapid sectoral shifts from agriculture and manufacturing towards services, the relationship between agriculture and RDISK did not change significantly in the period 1997-2017.

\section{Conclusions}

We investigated the relationship between the economic structure and resilience of Slovak (non)metropolitan regions in the period 1997-2017. More specifically, we asked if, and to what extent, prospects of regional economic resilience were associated with the sectoral structure of the economy and overall economic diversity/unrelated variety and the importance of other intervening variables (including regional contextual factors). Regional economic resilience was measured by the synthetic Regional Development Index (RDISK), calculated as a mean of four indicators (including sociodemographic variables): age structure of the population, net migration, income per capita and registered unemployment rate. Slovak districts were chosen to illustrate the long-term effects of economic structure on regional economic resilience in a period of high unemployment volatility and rapid structural changes affected by deindustrialization, restructuring of the former socialist enterprises, an inflow of FDI and global economic recession. Nevertheless, the effects of sectoral structure, economic diversity and also geographical location were surprisingly consistent and have not changed significantly since 1997. This conclusion suggests that the character of regional economic restructuring in Central Europe was, despite many changes, path-dependent, especially in non-metropolitan regions (see [10] for similar conclusions from Czechia).

The industrial, firm size and sectoral structure of employment are typical explanatory variables in studies explaining the regional differences in economic resilience. While economic diversity/unrelated variety and the presence of non-cyclical industries such as agriculture or public services are important predictors of a short-term resistance/recovery or unemployment volatility, as suggested by $[2,4,8,47]$ and many other authors. We did not find support for the assumption that these effects systematically impacted the long-term prospects of regional economic development.

To answer the first and second research questions, our empirical results clearly showed that the effects of vertical and horizontal geographic location, together with regional contextual factors, were significantly stronger predictors of regional economic resilience than industrial and firm size structure. Interestingly, while we failed to find any significant association between the economic structure and regional economic resilience in 1997, these relationships started to be significant in 2007. These findings confirm the assumption that, during the 1990s, regional contextual factors (see [91] for a discussion of this term), partly inherited from the socialist era, obscured the effects of industrial and firm size structure. After the privatization and integration of the Slovak economy into the global production networks through the inflow of foreign direct investment and other mechanisms, the effects of industrial and firm size structure, empirically proven in many countries, appeared to also be significant in Slovakia. Apart from the specific features of Slovak socioeconomic transition, privatization, entrepreneurial development and FDI inflow, two possible explanations might have more general validity.

Firstly, even in small, developed countries such as Slovakia, the effects of economic structure on regional development might be obscured by the position of district towns in an urban hierarchy and their transport accessibility. The historical west-east gradient in the social and economic development of Slovak districts originated in the industrial era and persisted over three completely different periods: socialist (1948-1989), transition (1990-2006) and integration period (since 2007). Therefore, inherited socioeconomic status was a more important predictor of the current and future development of non-metropolitan regions than industrial specialization/diversity, sectoral and firm size structure in the 1990s and later. These macro-level polarizations ('rich west vs. poor east') are surprisingly 
persistent, affecting the pace of socio-economic development of non-metropolitan regions for decades.

The second explanation is methodological: the observed effects of economic structure on resilience measured solely by the unemployment rate/GDP/gross value added per capita might be different from the effects on resilience measured by the RDI $\mathrm{IS}_{\mathrm{SK}}$. Regions that experienced rapid income growth might also suffer from temporarily high unemployment and outmigration. Correspondingly, economically deprived regions might have experienced relatively favourable demographic development due to their residential/environmental quality or ethnic minorities characteristic by higher fertility rates. Although regional patterns of demographic, social and economic indicators differ significantly, the synthetic indicator combining these dimensions was also associated with regional economic structure and was sensitive to the fluctuation of economic growth at the national level.

Finally, let us summarize the most important empirical result of our paper and draw some policy implications related to smart specialization. The lack of a systematic relationship between the industrial/firm size/sectoral structure and regional development documents a key role of two factors: (i) long cycles of regional evolutionary features including the inherited place-specific socioeconomic endowments [92] and (ii) agents, including the political representatives at a local, regional and national level, domestic and foreign entrepreneurs) who might substantially alter growth paths in their respective territories [93] through governance, entrepreneurship and innovation activity. Because many Slovak non-metropolitan and peripheral districts showed rather limited economic diversification and maintained their traditional specialization in (medium)-low tech industries [81], policy support of extra-regional trade and knowledge linkages were of vital importance for their long-term prosperity [94]. This should be combined with policies/initiatives leading to a stabilization of the local population and stimulation of entrepreneurial activity. Considering our conclusions, that the potential accessibility and distance from Wien were the most important predictors of regional development, investment in connectivity, as one of three pillars of the smart specialization [48], is crucial.

Supplementary Materials: The following are available online at https: / www.mdpi.com/article / 10.3390/land10121335/s1, File S1: Dataset: economic resilience of Slovak (non)metropolitan districts 1997-2017.

Author Contributions: Conceptualization, J.Ž. and M.C.; methodology, J.Ž.; software, V.S.; validation, J.Ž.; formal analysis, J.Ž.; investigation, J.Ž.; resources, J.Ž.; data curation, J.Ž., L.K., V.S. and M.C.; writing—original draft preparation, J.Ž., V.S. and L.K.; writing—review and editing, J.Ž. and V.S.; visualization, V.S. and M.C.; supervision, J.Ž.; project administration, J.Ž.; funding acquisition, J.Ž. All authors have read and agreed to the published version of the manuscript.

Funding: This research paper was written as a part of a research project of a long-term intersectoral collaboration "Smart technologies for the improvement of quality of life in cities and regions", identification number CZ.02.1.01/0.0/0.0/17_049/0008452. This project is funded by European Union Social Fund, Operational Programme "Research, Development and Education" led by the "Ministry of Education, Youth and Sports of the Czech Republic". The leader of the project consortium is the Faculty of Science, University of Ostrava.

Institutional Review Board Statement: Not applicable.

Informed Consent Statement: Not applicable.

Data Availability Statement: The data presented in this study are available as Supplementary Materials.

Acknowledgments: We thank Jaroslav Rusnák for providing us the database of economic data for Slovak districts. We also thank our colleague Lukáš Varecha for helping us with the design of the maps.

Conflicts of Interest: The authors declare no conflict of interest. 


\section{References}

1. Baldwin, J.R.; Brown, W.M. Regional manufacturing employment volatility in Canada: The effects of specialisation and trade. Pap. Reg. Sci. 2004, 83, 519-541. [CrossRef]

2. Ezcurra, R. Unemployment volatility and regional specialization in the European Union. Reg. Stud. 2011, 45, 1121-1137. [CrossRef]

3. Giannakis, E.; Bruggeman, A. Determinants of regional resilience to economic crisis: A European perspective. Eur. Plan. Stud. 2017, 25, 1394-1415. [CrossRef]

4. Giannakis, E.; Bruggeman, A. Regional disparities in economic resilience in the European Union across the urban-rural divide. Reg. Stud. 2020, 54, 1200-1213. [CrossRef]

5. Fratesi, U.; Rodríguez-Pose, A. The crisis and regional employment in Europe: What role for sheltered economies? Camb. J. Reg. Econ. Soc. 2016, 9, 33-57. [CrossRef]

6. Crescenzi, R.; Luca, D.; Milio, S. The geography of the economic crisis in Europe: National macroeconomic conditions, regional structural factors and short-term economic performance. Camb. J. Reg. Econ. Soc. 2016, 9, 13-32. [CrossRef]

7. Faggian, A.; Gemmiti, R.; Jaquet, T.; Santini, I. Regional economic resilience: The experience of the Italian local labor systems. Ann. Reg. Sci. 2018, 60, 393-410. [CrossRef]

8. Martin, R.; Sunley, P.; Gardiner, B.; Tyler, P. How Regions React to Recessions: Resilience and the Role of Economic Structure. Reg. Stud. 2016, 50, 561-585. [CrossRef]

9. Xiao, J.; Boschma, R.; Andersson, M. Resilience in the European Union: The effect of the 2008 crisis on the ability of regions in Europe to develop new industrial specializations. Ind. Corp. Change 2018, 27, 15-47. [CrossRef]

10. Ženka, J.; Novotný, J.; Slach, O.; Květoň, V. Industrial specialization and economic performance: A case of Czech microregions. Nor. Geogr. Tidsskr. 2015, 69, 67-79. [CrossRef]

11. Sánchez-Zamora, P.; Gallardo-Cobos, R. Diversity, disparity and territorial resilience in the context of the economic crisis: An analysis of rural areas in Southern Spain. Sustainability 2019, 11, 1743. [CrossRef]

12. Carlsson, E.; Steen, M.; Sand, R.; Nilsen, S.K. Resilient peripheral regions? The long-term effects of ten Norwegian restructuring programmes. Nor. Geogr. Tidsskr. 2014, 68, 91-101. [CrossRef]

13. Van Aswegen, M.; Retief, F.P. The role of economic sectoral structure as a policy mechanism towards more resilient peripheral regions: The case of South Africa. GeoJournal 2021, 86, 2823-2843. [CrossRef]

14. Evenhuis, E. The Political Economy of Adaptation and Resilience in Old Industrial Regions: A Comparative Study of South Saarland and Teeside. Ph.D. Thesis, Newcastle University, Newcastle, UK, 2016.

15. Hu, X.; Hassink, R. Exploring adaptation and adaptability in uneven economic resilience: A tale of two Chinese mining regions. Camb. J. Reg. Econ. Soc. 2017, 10, 527-541. [CrossRef]

16. Tan, J.; Hu, X.; Hassink, R.; Ni, J. Industrial structure or agency: What affects regional economic resilience? Evidence from resource-based cities in China. Cities 2020, 106, 102906. [CrossRef]

17. Urso, G.; Modica, M.; Faggian, A. Resilience and sectoral composition change of Italian inner areas in response to the great recession. Sustainability 2019, 11, 2679. [CrossRef]

18. Beaudry, C.; Schiffauerova, A. Who's right, Marshall or Jacobs? The localization versus urbanization debate. Res. Policy 2009, 38, 318-337. [CrossRef]

19. Duranton, G.; Puga, D. Diversity and specialisation in cities: Why, where and when does it matter? Urban Stud. 2000, 37, 533-555. [CrossRef]

20. Henderson, V. Medium size cities. Reg. Sci. Urban Econ. 1997, 27, 583-612. [CrossRef]

21. Henderson, V. Marshall's scale economies. J. Urban Econ. 2003, 53, 1-28. [CrossRef]

22. Ženka, J.; Slach, O.; Pavlík, A. Economic resilience of metropolitan, old industrial, and rural regions in two subsequent recessionary shocks. Eur. Plan. Stud. 2019, 27, 2288-2311. [CrossRef]

23. Hassink, R. The strength of weak lock-ins: The renewal of the Westmünsterland textile industry. Environ. Plan. A 2007, 39, 1147-1165. [CrossRef]

24. Schamp, E.W. Decline of the district, renewal of firms: An evolutionary approach to footwear production in the Pirmasens area, Germany. Environ. Plan. A 2005, 37, 617-634. [CrossRef]

25. Ženka, J.; Slach, O.; Sopkuliak, A. Typologie českých nemetropolitních regionů z hlediska faktorů, mechanismů a aktérů regionálního rozvoje. Geografie 2017, 122, 281-309. [CrossRef]

26. Smith, A. From convergence to fragmentation: Uneven regional development, industrial restructuring, and the "transition to capitalism" in Slovakia. Environ. Plan. A 1996, 28, 135-156. [CrossRef]

27. Korec, P. Štrukturálne zmeny ekonomiky Slovenska v prvej etape spoločenskej transformácie v regionálnom kontexte. Geogr. Moravica 2009, 1, 11-26.

28. Rusnák, J.; Bystrická, S. Osobitosti vývoja sektorovej štruktúry na Slovensku po roku 1989. Geogr. Čas. 2010, 62, 165-178.

29. Lauko, V.; Křižan, F.; Gurňák, D. Časovo-priestorové aspekty nezamestnanosti na Slovensku v procese ekonomickej transformácie a krízy. In Proceedings of the XII Mezinárodní Kolokvium o Regionálníh Vědách, Bořetice, Czech Republic, 12-14 June 2009; pp. 58-66.

30. Martin, R.; Sunley, P. On the notion of regional economic resilience: Conceptualization and explanation. J. Econ. Geogr. 2015, 15, 1-42. [CrossRef] 
31. Urruty, N.; Tailliez-Lefebvre, D.; Huyghe, C. Stability, robustness, vulnerability and resilience of agricultural systems. A review. Agron. Sustain. Dev. 2016, 36, 15. [CrossRef]

32. Kitano, H. Biological robustness. Nat. Rev. Genet. 2004, 5, 826-837. [CrossRef]

33. Pavlínek, P.; Ženka, J. Value creation and value capture in the automotive industry: Empirical evidence from Czechia. Environ. Plan. A 2015, 48, 937-959. [CrossRef]

34. Foray, D. On the policy space of smart specialization strategies. Eur. Plan. Stud. 2016, 24, 1428-1437. [CrossRef]

35. Boschma, R. Towards an Evolutionary Perspective on Regional Resilience. Reg. Stud. 2015, 49, 733-751. [CrossRef]

36. Martin, R. Regional economic resilience, hysteresis and recessionary shocks. J. Econ. Geogr. 2012, 12, 1-32. [CrossRef]

37. Frenken, K.; Van Oort, F.; Verburg, T. Related variety, unrelated variety and regional economic growth. Reg. Stud. 2007, 41, 685-697. [CrossRef]

38. Pavlík, A.; Ženka, J. Economic resilience of European rural regions in 2000-2016: A case study of four EU countries. Geogr. Cassoviensis 2021, 14, 178-191.

39. Giannakis, E.; Bruggeman, A. Exploring the labour productivity of agricultural systems across European regions: A multilevel approach. Land Use Policy 2018, 77, 94-106. [CrossRef]

40. Mattas, K.; Tsakiridou, E. Shedding fresh light on food industry's role: The recession's aftermath. Trends Food Sci. Technol. 2010, 21, 212-216. [CrossRef]

41. Hennebry, B.; Stryjakiewicz, T. Classification of Structurally Weak Rural Regions: Application of a Rural Development Index for Austria and Portugal. Quaest. Geogr. 2020, 39, 5-14. [CrossRef]

42. Davies, S. Regional resilience in the 2008-2010 downturn: Comparative evidence from European countries. Camb. J. Reg. Econ. Soc. 2011, 4, 369-382. [CrossRef]

43. Lagravinese, R. Economic crisis and rising gaps North-South: Evidence from the Italian regions. Camb. J. Reg. Econ. Soc. 2015, 8, 331-342. [CrossRef]

44. Duranton, G.; Puga, D. Nursery Cities: Urban Diversity, Process Innovation, and the Life Cycle of Products. Am. Econ. Rev. 2001, 91, 1454-1477. [CrossRef]

45. Hassink, R. How to unlock regional economies from path dependency? From learning region to learning cluster. Eur. Plan. Stud. 2005, 13, 521-535. [CrossRef]

46. Dissart, J.C. Regional economic diversity and regional economic stability: Research results and agenda. Int. Reg. Sci. Rev. 2003, 26, 423-446. [CrossRef]

47. Martin, R.; Sunley, P. Path dependence and regional economic evolution. J. Econ. Geogr. 2006, 6, 395-437. [CrossRef]

48. McCann, P.; Ortega-Argilés, R. Smart Specialization, Regional Growth and Applications to European Union Cohesion Policy. Reg. Stud. 2015, 49, 1291-1302. [CrossRef]

49. Chinitz, B. Contrasts in Agglomeration: New York and Pittsburgh. Am. Econ. Rev. 1961, 51, $279-289$.

50. Drucker, J.; Feser, E. Regional industrial structure and agglomeration economies: An analysis of productivity in three manufacturing industries. Reg. Sci. Urban Econ. 2012, 42, 1-14. [CrossRef]

51. Isaksen, A.; Karlsen, J. Can small regions construct regional advantages? The case of four Norwegian regions. Eur. Urban Reg. Stud. 2013, 20, 243-257. [CrossRef]

52. Kemeny, T.; Storper, M. Is Specialization Good for Regional Economic Development? Reg. Stud. 2015, 49, 1003-1018. [CrossRef]

53. Hassink, R.; Gong, H. Six critical questions about smart specialization. Eur. Plan. Stud. 2019, 27, 2049-2065. [CrossRef]

54. Percoco, M. Strategies of regional development in European regions: Are they efficient? Camb. J. Reg. Econ. Soc. 2013, 6, 303-318. [CrossRef]

55. Balland, P.A.; Boschma, R. Complementary interregional linkages and Smart Specialisation: An empirical study on European regions. Reg. Stud. 2021, 55, 1059-1070. [CrossRef]

56. Foray, D.; Goenaga, X. The Goals of Smart Specialisation; JRC Scientific and Policy Report; S3 Policy Brief Series; Publications Office of the European Union: Luxembourg, 2013.

57. Combes, P.; Duranton, G.; Gobillon, L.; Puga, D.; Roux, S. The productivity advantages of large cities: Distinguishing agglomeratiom from firm selections. Econometrica 2012, 80, 2543-2594. [CrossRef]

58. Burger, M.J.; Meijers, E.J.; Hoogerbrugge, M.M.; Tresserra, J.M. Borrowed Size, Agglomeration Shadows and Cultural Amenities in North-West Europe. Eur. Plan. Stud. 2015, 23, 1090-1109. [CrossRef]

59. Keeble, D.; Tyler, P. Enterprising Behaviour and the Urban-Rural Shift. Urb. Stud. 1995, 32, 975-997. [CrossRef]

60. Asheim, B.T.; Coenen, L. Knowledge bases and regional innovation systems: Comparing Nordic clusters. Res. Policy 2005, 34, 1173-1190. [CrossRef]

61. Helburn, N. Geography and the Quality of Life. Ann. Assoc. Amer. Geogr. 1982, 72, 445-456. [CrossRef]

62. Terzo, G. Social capital, social economy and economic resilience of Italian provinces. Pap. Reg. Sci. 2021, 100, 1113-1135. [CrossRef]

63. Slach, O.; Rumpel, P.; Koutský, J. Profilace Měkkých Faktorů Regionálního Rozvoje; Accendo O.P.S.: Ostrava, Czech Republic, 2013; ISBN 978-80-904810-7-7.

64. Mulligan, G.F.; Carruthers, J.I. Investigating Quality of Urban Life Theory, Methods, and Empirical Research. Soc. Indic. Res. 2011, 45,450 . 
65. Lambiri, D.; Biagi, B.; Royuela, V. Quality of life in the economic and urban economic literature. Soc. Indic. Res. 2007, 84, 1. [CrossRef]

66. Reissová, A.; Šimsová, J.; Sonntag, R. Moving across Borders: Brain or brain gain? A comparative in Czechia and Germany. GeoScape 2021, 15, 30-42. [CrossRef]

67. Abreu, I.; Nunes, J.M.; Mesias, F.J. Can Rural Development Be Measured? Design and Application of a Synthetic Index to Portuguese Municipalities. Soc. Indic. Res. 2019, 145, 1107-1123. [CrossRef]

68. OECD. Redefining Urban: A New Way to Measure Metropolitan Areas; OECD: Paris, France, 2012.

69. Korec, P.; Ondoš, S.; Rusnák, J. Regionálne disparity na Slovensku: Niekol'ko poznámok k ich bádaniu. Acta Geogr. Univ. Carol. 2016, 60, 257-293.

70. Korec, P.; Polonyová, E. Zaostávajúce regióny Slovenska-Pokus o identifikáciu a poukázanie na pričíny. Acta Geogr. Univ. Comen. 2011, 55, 165-190.

71. SOSR. Hrubá Miera Migračného Salda [Net Migration as a Share of the Total Population]; Statistical Office of the Slovak Republic: Bratislava, Slovakia, 2020.

72. SOSR. Indexy Vekového Zloženia [Demographic Indexes of the Age Structure]; Statistical Office of the Slovak Republic: Bratislava, Slovakia, 2020.

73. SOSR. Mzdy Podle Ekonomickej Činnosti Zistené Pracoviskovou Metódou. [Wages According to the Economic Activity Aggregated from the Plant-Level Data]; Statistical Office of the Slovak Republic: Bratislava, Slovakia, 2020.

74. SOSR. Miera Evidovanej Nezamestnanosti. [Average Net Nominal Monthly Wage]; Statistical Office of the Slovak Republic: Bratislava, Slovakia, 2020.

75. Rodrigue, J.P.; Comtois, C.; Slack, B. The Geography of Transport Systems; Routledge: London, UK; New York, NY, USA, 2020.

76. Randák, J.; Marada, M.; Vrtiška, M. Application of potential accessibility models in decision-making on HSR routing: The case of Rapid Connections in Czechia. Acta Univ. Carol. Geogr. 2021, 56, 108-119. [CrossRef]

77. Geodetický a Kartografický Ústav Bratislava Geoportál. Available online: https://www.geoportal.sk/sk/geoportal.html (accessed on 11 October 2021).

78. Rusnák, J.; Lehocký, F. Priestorová distribúcia a sektorová štruktúra priemyslu na Slovensku. Acta Geogr. Univ. Comen. 2016, 60, 69-102.

79. Korec, P. Vplyv post-industriálného štádia vývoja spoločnosti a globalizácie na regionálný vývoj Slovenska. Geogr. Cassoviensis 2007, 1, 75-80.

80. Baláž, V. Regional Polarization under Transition: The Case of Slovakia. Eur. Plan. Stud. 2007, 15, 587-602. [CrossRef]

81. Rusnák, J.; Lehocký, F. Agglomeration economies and technology intensity of industry sector in Slovakia. Polit. Ekon. 2019, 67, 426-443. [CrossRef]

82. Šprocha, B.; Bačík, V. Transformácia plodnosti na Slovensku v čase a priestore. Geogr. Cassoviensis 2021, 15, 37-55. [CrossRef]

83. Smith, A. Uneven development and the restructuring of the armaments industry in Slovakia. Trans. Inst. Br. Geogr. 1994, 19, 404-424. [CrossRef]

84. Rajčaková, E.; Švecová, A. Regionálne disparity na Slovensku. Geogr. Cassoviensis 2009, 2, 142-149.

85. Tsenkova, S. Beyond transitions: Understanding urban change in post-socialist cities. In The Urban Mosaic of Post-Socialist Europe; (Contributions to Economics); Physica-Verlag HD: Heidelberg, Germany, 2006; pp. 21-50.

86. Heidenreich, M. Die mitteleuropäische Großindustrie im Transformationsprozeß. Z. Soziol. 1994, 23, 3-21. [CrossRef]

87. Hübelová, D.; Ptáček, P.; Šlechtová, T. Demographic and socio-economic factors influencing health inequalities in the Czech Republic. GeoScape 2021, 15, 53-65. [CrossRef]

88. Tvrdoň, J.; Hamalová, M.; Žárská, E. Regionálny Rozvoj; Ekonóm: Bratislava, Slovakia, 1995.

89. Caruso, G.; Di Battista, T.; Gattone, S.A. A Micro-level Analysis of Regional Economic Activity Through a PCA Approach. In Decision Economics: Complexity of Decisions and Decisions for Complexity; Bucciarelli, E., Chen, S.H., Corchado, J.M., Eds.; Springer: Berlin/Heidelberg, Germany, 2020; pp. 227-234, ISBN 978-3-030-38227-8.

90. Viturka, M.; Pařil, V. Evaluation of the effectiveness of high-speed rail projects in the Czech Republic in terms integration potential. GeoScape 2020, 14, 1-10. [CrossRef]

91. Halada, M.; Ženka, J. Microregional patterns of corporate philanthropy: The role of economic structure and regional determinants. GeoScape 2020, 14, 24-35. [CrossRef]

92. Iammarino, S.; Rodriguez-Pose, A.; Storper, M. Regional inequality in Europe: Evidence, theory and policy implications. J. Econ. Geogr. 2019, 19, 273-298. [CrossRef]

93. Grillitsch, M.; Sotarauta, M. Trinity of change agency, regional development paths and opportunity spaces. Prog. Hum. Geogr. 2020, 44, 704-723. [CrossRef]

94. Balland, P.A.; Boschma, R.; Crespo, J.; Rigby, D.L. Smart specialization policy in the European Union: Relatedness, knowledge complexity and regional diversification. Reg. Stud. 2019, 53, 1252-1268. [CrossRef] 